\title{
Employee Turnover Intention in services sector of Pakistan
}

\author{
Ehsan Ullah Bajwa \\ Department of Management Sciences, The Islamia University of Bahawalpur, Pakistan \\ Email: ehsanullahbajwa2004@gmail.com \\ Muhammad Yousaf \\ Department of Management Sciences, The Islamia University of Bahawalpur, Pakistan \\ Email: mohammadyousaf1990@gmail.com
}

Muhammad Rizwan

Department of Management Sciences, The Islamia University of Bahawalpur, Pakistan

Email: rizwan.arshad@iub.edu.pk

Doi:10.5296/ ijhrs.v4i2.5905 URL: http://dx.doi.org/10.5296/ ijhrs.v4i2.5905

\begin{abstract}
The idea of Employee Turnover Intention (ETI) is becoming hot topic for multinational, domestic and local organizations, even in the government organization's and private companies. So few of the scholars have discussed many factors which influence the ETI variable, so therefore some of the factors are discussed those are Workplace Environment, Job Satisfaction and Job Performance which give positive effect on ETI. As the studies which are already done on the services sector of Pakistan are not much on the factors like Workplace Environment (WPE) and Job Performance (JP). So the main purpose of that study is to check the influence of WPI, JP and JS on the ETI in the services sector of Pakistan. The total sample size of the respondents of different employees from high level of income to low level of income the data was collected from them were 200, so then the data was processed by using multiple regression analysis software. So we found that job satisfaction(JS), job performance(JP), workplace environment(WPE) give an impact on employee turnover intention(ETI) in the services sector of Pakistan.
\end{abstract}

Keywords: Employee turnover intention, Job satisfaction, Job performance \& Workplace environment. 


\section{Introduction}

The definition of ETI is the quitting of the any employee from the organization willingly is called as ETI. "Who cause affect on ETI?" So the employees who are thinking to leaving their job has very important question to answer this, the managers also have to bear the high cost of instability of continuous leaving of their employees. This high cost is incurred due to the recruitment of the new employees on their orientation, training and development so they can perform well and increase the organization efficiency. But the main focus is on the quitting of job of the employee's and this is the factor of interest for the researcher's, who are working on ETI. So the quitting of the employee's shows their strong behavior which is observed by the researchers. It is very important for both the individual's and at the manager's end to understand the variables which affect their leaving company these are JS, JP, WPE and ETI. Job Satisfaction is one of the most important variables that participate on employee's to leave their job.

Purpose of writing that paper is to measure the affect of job performance (JP) and person companies fit on the ETI in the services sector of Pakistan. There had been not much work done on the particular area on services sector of Pakistan. So that research paper will open the gates for the readers and researchers to do researches on that. The distribution of such certificates of recognition, cross training programs and providing incentive must be added in the company which can help strongly in reducing the ETI of the company and that can also help in creation of healthy environment. For example, few companies introduced bonus programs for services sector of Pakistan; some rewards are also given on the bases of attendance records for those who achieved already established rules (WERC Sheet, 2000). Similarly, J.Jill introduced performance based benefits programs that are known as Base Plus which were made specially to improve JP with mutual benefits for the employee and the company (Reda, 2001). That program by J.Jill help him not only in reducing work force but also help him in resolving the shortage of the employee, it increases the productivity of labor.

Individuals tend to compare themselves with their co-workers in positions above and below them in the hierarchy as on the basis for assessing their own performance (Major et al., 1991; Sheppard et al., 1992). Social comparison has been theorized to be an important predictor of outcome expectations and job satisfaction (Oldham et al., 1986). Social comparisons are deeply embedded in organizational life, supervisors compare employees' performance relative to others when conducting performance appraisals, and employees often compare their pay and job rewards with those of their coworkers (Greenberg et al., 2007). In turn, social comparisons are expected to impudence employees' attitudes and adjustments (Brown et al., 2007). Understanding how individual's social appraisal of a situation can contribute to their career attitudes may be important for organizations trying to foster motivation, productivity and organizational culture (Buunk et al., 2003).

Research in the organizational context has highlighted the motives associated with upward and downward comparisons in an effort to understand employee attitudes (i.e. Brown et al., 2007; Buunk and Gibbons, 2007). Upward and downward comparisons are related with the self-evaluation motive, upward comparisons are commonly related to the self-improvement 
motive and downward comparisons to the self-enhancement motive (Berger, 1977; Buunk and Gibbons, 2007; Wood and Taylor, 1991). However, recently researchers have called for a more complex view of social comparisons (Buunk and Gibbons, 2007; Greenberg et al., 2007). That is they have called for research that investigates when upward comparisons are inspiring versus threatening and when downward comparisons are associated with pride versus fear that one's situation could worsen. Thus, to advance social comparison research studies need to focus not only on the various functions and outcomes of social comparisons but also on the fact that people differ in their tendencies to compare themselves to others and on the implications of these differences (Buunk and Gibbons, 2007). Turnover tells us that many of the employees don't have much familiarity with their working environment so they are working in difficult conditions like risk and exposure.

ETI may have negative impact on the organizational culture. So it is very important to understand the turnover in services sector of Pakistan (SSOP). The value of understanding staff turnover in the solutions market of Pakistan is obvious when the competition for skilled workers between companies is considered. By determining the factors of employees' objective to keep, turnover actions could be expected more precisely and actions to prevent turnover could be taken in advance (Hwang \& Kuo, 2006). Low worker involvement results in objective to leave (Firth, Mellor, Moore \& Loquet, 2004; Harter, Schmidt \& Hayes, 2002). Work-family issue is considered to adversely affiliate with, job fulfillment, depressive disorders, panic attacks, feelings conditions, health problems, high blood pressure, and booze (Matthewsa et al., 2011). It is a generally organised perception, especially among financial market, that perform and close relatives are two separate life inside them.

To a large level this program also allows comprehensive tracking of worker performance (Hutchinson et al., 2000). The SSOP workplace is recognized as being similar to set up line manufacturing (Taylor and Bain, 1998). In most SSOP, performance includes dyadic communications between workers and customers rather than group connections among categories of workers. The transactions between workers and customers in the services sector are highly scripted and there are no face-to-face connections between them, thus leading to low levels of recognized job control (Varca, 2001). ETI has produced comprehensive scholarly literary works. The current literary works on ETI concentrates on aspects recognized to be of concern to the market. Current research points to the wage level (Stephenson and Fox, 1996), expertise and proficiency of the dispatcher (Keller, 2002; Keller and Ozment, 1999a, b), selection techniques (Min and Emam, 2003), stress and exhaustion (de Croon et al., 2004) and leader-member trade (Morrow et al., 2005) as aspects that influence the decision of employee to leave their organization.

Job fulfillment is one of the most widely analyzed work-related behaviour in the field of commercial and business mindset, and business actions (Spector, 1997). Greenberg and Baron (1997) define job fulfillment as your intellectual, effective and evaluative responses towards his or her job. When an individual perceives that he or she does not provide desirable and unique resources or abilities to an organization, the adaptive response is to find another niche to occupy by searching for another job (Brown et al., 2007). The self-improvement motive of upward comparisons may thereby intensify an individual's turnover intentions in an 
effort to improve his or her position in another organization. Indeed, individuals who frequently make upward comparisons, focusing on how others are doing better than oneself, have been found to display more job search behaviors than those who frequently make downward comparisons (Buunk et al., 2003). While a person who regularly creates way up evaluations may appreciate a individual doing better than yourself (Buunk et al., 2003; Gill et al., 2013), this way up evaluation can also generate emotions of jealousy and inferiority (i.e. Diener and Fujita, 1997; Thornton and Moore, 1993), increasing his or her turnover intentions.

\section{Literature Review:}

All organizations have different rate of turnover. Normally private sector has the highest rate of turnover as compared to public sector. Even the levels of turnover are found to be variable in area-to-area study. The areas, which have low unemployment rate and where it is easier for the people to get an alternate job, have highest rates of turnover. At sometimes a company is positively benefitted by the employee's turnover.

The reason may be replacement of a low-grade performer by a very high-grade performer or may an old, aged worker retire, and the new induction is younger and more skilled. Employee turnover intention (ETI) may be also costly, because it requires different cost to take account for example administrative costs of recruitment cost for the duration in which there is a vacancy, cost for the training for the new employee etc.

There are different factors that cause ETI. Like sometimes, new job attracts employees and compel them to leave the previous one when conditions at present workplace does not match his/her family requirements .Another reason maybe the poor working relationship between the employee and employer. It is rarely observed that people having a good working environment rarely leave the job even if offered better salaries elsewhere. Improper training and less chances of development are also key causes for the voluntary turnover. Job security is the preference of every employee.

The management after removing the negative factors can control turnover. These may include provision of proper training to the to-be-managers for an effective supervision before upgrading or appointing them, providing job security with good working environment etc. Existing managers can be re-trained provided those have a poor record at keeping their staff merrily.

Supervisors who are managers could be answerable for ETI in their teams. Increase of opportunities for individual employees such as to accommodate individual preferences on working hours, regular appraisals, providing as much job security as possible can help to reduce turnover. Turnover marks business efficiency and as such, it allows attention and some knowing of itself. Furthermore, however details on turnover can help the preparation, forecast and management of sources. Despite a tremendous literary works on turnover in companies, there is yet no globally approved consideration or frame- work for why people select to quit. The trend of turnover is of attention to companies and advocates because it is important, possibly expensive and relatively clear-cut. It also explains that it is caused by a choice 
procedure.

The objective of 'effective management of turnover' demands that an advanced level of complexity, and thereby particularly, needs to be obtained by companies to be able to precisely impact the revenues procedure. However, the trend has not so far shown be influenced by the forecast. Although some studies have targeted on prospective predictors of ETI actions, such as job period, location of management etc.

\subsection{Employee Turnover Intention (ETI):}

Worker turnover is an important problem especially in the area of Individual Source Control. It is working on market purification level on the costs associated with great ETI. ETI cost include cost of choosing and choosing of new employees and as well as the cost of loss of sales due to the low skills of new employee. If staff programs to quit and is given a salary rise keeping in mind the effects of ETI on the organization.

Bodla\&Hameed (2008) suggested that the ETI would have important price or chance of dropping public investment. The analysis further concludes that the measurement of the ETI objective, which is a controllable and uncontrollable phenomenon. There are five different factors that been identified so far, which is the satisfaction with pay, satisfaction with working circumstances, satisfaction with support, business commitment, and Job pressure.

According to Jeffrey (2007), if the doubt of control is chronic then unhappiness among employees would cause the decrease of job interval, improving the turnover and objective to quit. Therefore, organization should not ignore this aspect.

Froese (2011) indicates that the five measurement of intercultural connections are used to be expected from the participants' cross-cultural adjustment and execute a behavior. The different connections and issue style are exposed by the associates from Anglo- Saxon nations efficient with The Japanese lifestyle. The first measurement is the associates must be skilled in wide range of country languages, in order to reduce the negative effect on execution of related adjustment. The second is a connection in English has a positive effect on expatriates' execute adjustment. Third, is the worldwide employee with indirect connections styles may be more likely to show cross-cultural adjustment and job fulfillment and less likely to show ETI goals than those with direct connections styles. 4th is the, worldwide employees with competitive issue styles may less likely to show cross-cultural adjustment and job fulfillment and more likely to show ETI goals. Fifth, the worldwide worker can have more regular connection with wide range of country employees in the workplace. This display modification mismatched and connections styles may cause the doubt and conflicts in the workplace, making worldwide employees frustrated with their projects and consider quitting the company.

ETI objectives can be categorized into unpreventable turnover, appropriate turnover and unwanted turnover. The unpreventable turnover is due to as well as, family issues or old age. Moreover, the appropriate turnover is due to the worker's mess. Last but not least, for unwanted turnover would consist of certified and certified employees making due to such organization problems as lack of support, inadequate support and part issue. These problems 
need to be resolved because they have an impact on client care high quality and organization performance (Shim, 2010; Rizwan et al., 2013).

\subsection{Workplace environment:}

Working circumstances symbolizes the workplace and factors of an employee's circumstances for employees working environment where they execute their work. This includes issues such as: the company of execute and execute activities; training, abilities and employability; health, protection and well-being; as well as time.

Physical operating conditions contain different factors about the job such as relaxed workplace, air flow, well-lit and temperature, bigger, better and neat workspaces, and workstations. These factors impact worker job fulfillment since employees want a workplace that provides more real comfort (Ceylan, 1998).Hence if such relaxed workplace is provided to the employees by the companies the ETI rate will decrease, worker fulfillment enhances. Some studies that show worker ETI levels can be mainly blamed to the real operating conditions (De Troyer, 2000):

\subsection{Job Satisfaction (JS):}

Job fulfillment is one of the most generally analyzed work-related behaviour in the fields of commercial and business mindset, and business actions (Spector, 1997). Greenberg and Baron (1997) define job fulfillment as your intellectual, effective and evaluative responses towards his/her job. Locke (1984) defined job fulfillment as the condition where someone's needs and someone's results coordinate well. According to Cranny et al. (1992), job fulfillment is a mixture of intellectual and effective responses to the differential views of what a worker wants to get in comparison to what he/she actually gets.

JS individuals compare and contrast themselves to others to figure out if their professions are effective (Heslin, 2003). Comparative deprival concept, an evaluation concept that creates upon the base of public evaluation concept (Conner, 2003), emphasizes relative compared to overall benefits in describing fulfillment with status-based benefits (Crosby, 1982; Martin, 1981). The concept suggests that when any person analyzes his/her benefits with those of a referent, emotions of deprival may outcome (Kulik and Ambrose, 1992). Social evaluations may cause individuals to become dissatisfied when "there is a difference between the outcome they want and what they receive" and "they see that an evaluation other has more than they do" (Sweeney et al., 1990, p. 423).

The comparison exposed from way up evaluations that may therefore decrease someone's feeling of success and self-efficacy (Greenberg et al., 2007). Indeed, researches have recommended that people who evaluate themselves to referents who execute better (Buunk et al., 2003) and generate more (Sweeney et al., 1990) usually experience limited and dissatisfied. In evaluation, evaluation results from downwards evaluations set a reduced blueprint against which to assess someone's unique circumstances (Brown et al., 2007) thus improving your understanding that he/she is advancing in his/her profession. Downward evaluations inflate someone's feeling of control and ability (Greenberg et al., 2007). The evaluation results associated with downwards evaluations often result in beneficial impact 
(Greenberg et al., 2007); improving your self-esteem and causing pleasure (Klein, 1997; Kulik and Gump, 1997). Research indicates that people who experience advantageous in evaluation to others are more satisfied with their tasks (Brown et al., 2007) and profession benefits (Oldham et al., 1986) than those who experience less advantageous.

A significant body of research has examined the connection between job fulfillment and ET objectives (Spector, 1997). In Mobley et al.'s (1978) ET design, discontentment is a sequence of drawback cognitions in which workers analyze the expenses and benefits associated with making their tasks. Eventually, this intellectual evaluation results in employees' drawback from the company. Hom et al. (1992), by mixing meta-analytic methods with architectural formula acting, offered proof for the Mobley et al. (1978) revenues design. In a more latest meta-analysis, Hellman (1997) revealed a mean fixed connection of 20.52 (p, 0.001) between job fulfillment and ET objectives. Although the connection between JS and ETI objectives is well recognized, we offer it as a speculation.

\subsection{Job Performance (JP):}

A growing body of analysis links great ETI rates to deficits in business performance. For example, one national study of nursing staff at 333 medical centers revealed that ETI among registered nurses included $68 \%$ of the variation in per-bed operating costs.8 Likewise, reducing ET level has been shown to improve sales growth and employees spirits. In addition, high-performance HR methods (including reduction of structural ETI rates) increase company success and market value. These relationships become even more noticeable when you consider who is leaving. For instance, analysis has revealed that great revenues among workers with comprehensive social capital can considerably deteriorate company performance. Thus, a smart HR manager can make a clear business case for developing revenues management strategies to the types of workers leaving the organization.

Much research on how skills can be kept has been based on knowing the different reasons behind employees' options to keep companies, as well as the procedures by which individuals make such options. By knowing why individuals keep, companies can also obtain a better idea of why individuals remain and can learn how to address these options. The concept of business equilibrium 13 can reduce useful light on these issues. According to this concept, any person will remain with a company as long as the incentives it provides (such as acceptable pay, good working circumstances, and creating opportunities) are similar to or higher than the efforts (time, effort) required of the person by the company. Moreover, these conclusions are suffering from both the person's wish to keep the company and the convenience with which he/she could leave. Clearly, ETI is a complicated process. That is, although some individuals may stop a job on reaction, most individuals who keep invest a while originally analyzing their present job against possible solutions, creating objectives about what to do, and interesting in various kinds of job- search actions.

The research has shown that specific ETI impact key job behaviour such as fulfillment with someone's part and dedication to the company. Low fulfillment and dedication can start the drawback procedure, such as thoughts of giving up, job searching, evaluation of alternative possibilities, and the objective to keep. This procedure may lead to ETI if the company is not 


\section{Macrothink}

able to handle it successfully. Reasons for turnover may also produce other performance-based actions that suggest drawback, such as absenteeism, lateness, and poor performance, any of which may end in a quitting without the person going through a job search, assessment of solutions, or prolonged consideration of giving up. The lesson? To proactively handle retention, companies must observe and modify key factors of the workplace that impact employees' desire to stay or quit. As we have seen, the ease with which the individual can quit a company results in the individual's choices.

When someone has lots of attractions that are more eye-catching than his/ her present part, the decision to leave becomes much easier. Supervisors, who are keen to keep their good workers, must keep an eye on different possibilities, so they can ensure that their roles stays in power. When eye-catching solutions are numerous, people usually assess their present workplace against a higher standard than when options are few. It may become more difficult for their company to keep them pleased, which is a task especially with greatly regarded employees in high-demand roles. With restricted sources, companies may choose to pay attention to focus on communities rather than trying to maintain every worker consistently. Based on what exactly is going on in the work market, companies may want to concentrate their storage initiatives on particular employees or categories of employees, such as new employs, celebrity artists, employees with high-demand or hard- to-replace skills, or members of particular population categories.

\section{Hypothesis and research model}

On the basis of above literature review, the current study tests the following hypothesis:

H1: There is a significant positive relationship between workplace environment and employee turnover.

$\mathrm{H} 2$ : There is a significant positive relationship between Jobs satisfaction and employee turnover.

H3: There is a significant positive relationship between Organizational Performance and employment turnover.

Figure 1: Hypothetical Model of that current research employee turnover;

Independent Variable

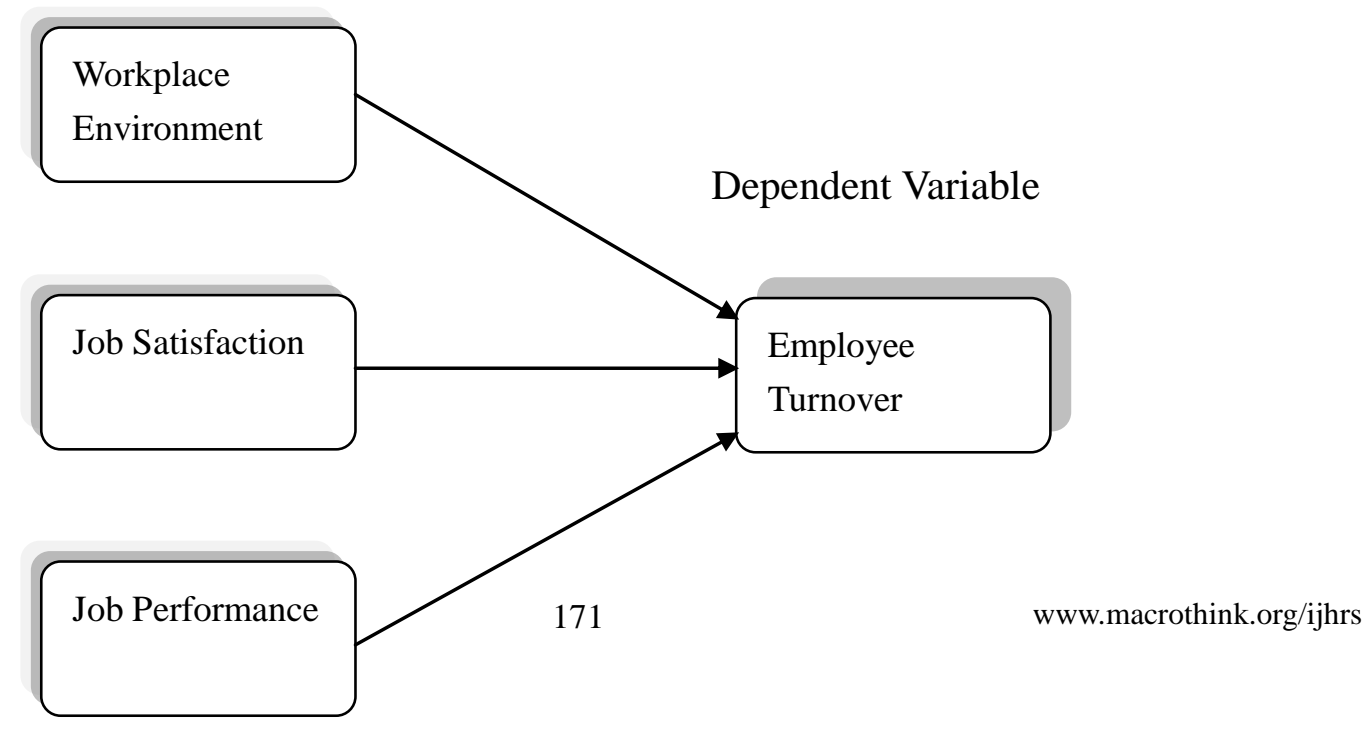




\section{Research Methodology:}

The present analysis is illustrative in its type. Descriptive analysis can be described as explaining something, some trend or any particular situation. Descriptive studies are those studies that explain the current circumstances instead of decoding and making conclusions (Creswell, 1994). The main goals of illustrative analysis is confirmation of the designed speculation that indicate the unique circumstances, this type of analysis provides information about the present situation and targets on past or present for example total well being in a group or client behaviour towards any marketing action (Kumar, 2005).

\subsection{Sample/Data:}

To gather the necessary information was used analysis method on unique the opportunity of analysis design. Service area was chose as a perfect analysis place in Pakistan. An example of 200 participants will ask to join in a self-administered questioner. The research was performed during the month of May 2013 at multiple companies for employees' research information was also gathered from Govt. Workers. A group of 200 team-members was chosen, however not all employees were able to reply to the surveys and only a complete of 150 questionnaires' were efficiently finished.

The current research runs on the non-probability testing strategy that is comfort testing. Convenience testing is a testing strategy that acquires and gathers the appropriate information from the example or the unit of the research that are easily available (Zikmund, 1997). Convenience testing is normally used for gathering a huge number of finished reviews quickly and with economic system (Lym et al., 2010). We select these examples from different companies in Bahawalpur Pakistan.

The main cluster will target to collect the sample data from the working professionals of different organizations. The selection of employees is commonly based on the previous results of the studies on employee turnover intention. The reasoning for the use of this strategy was that the study involved several separate factors associated to the reliant varying (ET and office environment). This was done using a five point range information principles (Strongly agree to strongly disagree) to estimate the ranking catalog on each of the signal established to impact the overall ET objective.

\subsection{Instrument and Measures:}

The survey instrument of the current study addresses two major purposes. First, analyze to relationship of different variables in the adoption of employee turnover intention. Second, to collect information about the different attribute of the respondents that can be used to understand the variation of different categories. The survey instruments contain two sections. Section 1 includes different personal and demographic variables. This section will obtain respondent's information about Name, Gender, Educational level, Income level and Age.

Section 2 includes latent variables that are important I the current study. These variables include Workplace environment, Job satisfaction, Job performance, and turnover intention. This Job overall performance, ET objective Office environment, Job fulfillment all are 


\section{Macrothink}

interlinked. This part of the research was developed based on the approved literary works and already used questioners.

The scales of the study were adopted from the previous literature and published studies. The first variable of the study was WPE have six items and this scale was taken from (Lee, 2006). The next variable is JS having six items was taken from (Daulatram B. Lund, 2003). The next variable is ETI and that variable have four items in it and was took from (Bluedorn, 1982). The last variable is JP having three items in it and was taken from (Bowraet al, 2011)

Table 1: Scales of the study;

\begin{tabular}{|c|c|c|c|}
\hline No. & Variable & Items & Reference \\
\hline 1 & $\begin{array}{l}\text { Employee } \\
\text { Turnover }\end{array}$ & $\begin{array}{l}\text { 1. I often think about quitting. } \\
\text { 2. It is likely that I will actively look for a } \\
\text { new job next year. } \\
\text { 3. I will probably look for a new job in the } \\
\text { next year. } \\
\text { 4. I often think of changing my job. }\end{array}$ & Bluedorn, 1982 \\
\hline 2 & $\begin{array}{l}\text { Job } \\
\text { Satisfaction }\end{array}$ & $\begin{array}{l}\text { 1. My organization is a very personal place. } \\
\text { It is like an extend family people seem to } \\
\text { share a lot of themselves. } \\
\text { 2. My organization is a very formalized and } \\
\text { structured place for established procedure } \\
\text { generally govern what people do. } \\
\text { 3. The head of my organization is generally } \\
\text { considered to be a coordinator, an } \\
\text { organizer, or an administrator. } \\
\text { 4. The glue that holds mu organizations } \\
\text { together is formal rule and policies. } \\
\text { Maintaining a smooth -running institution } \\
\text { is important here. } \\
\text { 5. The glue that holds my organization } \\
\text { together is commitment to innovation and } \\
\text { development. there is an emphasis on } \\
\text { being first. } \\
\text { 6. My organization emphasizes competitive } \\
\text { actions and achievement. Measurable }\end{array}$ & $\begin{array}{l}\text { Daulatram B. Lund, } \\
2003\end{array}$ \\
\hline
\end{tabular}




\begin{tabular}{|c|c|c|c|}
\hline & & goals are important. & \\
\hline 3 & $\begin{array}{l}\text { Job } \\
\text { Performance }\end{array}$ & $\begin{array}{l}\text { 1. My performance is better than that of my } \\
\text { colleagues with similar qualifications. } \\
\text { 2. I am satisfied with my performance } \\
\text { because it is mostly good. } \\
\text { 3. My performance is better than that of } \\
\text { employees with similar qualifications in } \\
\text { other organizations. }\end{array}$ & Bowraet al, 2011 \\
\hline 4 & $\begin{array}{l}\text { Workplace } \\
\text { Environment }\end{array}$ & $\begin{array}{l}\text { 1. My workplace provides an undisturbed } \\
\text { environment so that I can concentrate on } \\
\text { my work. } \\
\text { 2. My furniture is flexible enough to adjust, } \\
\text { rearrange, or reorganize my workspace. } \\
\text { 3. The quality of my equipment is more than } \\
\text { sufficient to work effectively. } \\
\text { 4. I am able to control temperature or air } \\
\text { flow in my office. } \\
\text { 5. My workstation is large. } \\
\text { 6. I am able to have quiet and undisturbed } \\
\text { time alone. }\end{array}$ & Lee, 2006 \\
\hline
\end{tabular}

\subsection{Procedure:}

The questionnaires were distributed in to 200 respondents in Bahawalpur. These respondents were selected on the bases of criteria that is discussed above. The purpose of study and questions were explained to the respondents so they can fill them easily the questionnaire with their relevant responses. A total of 150 questionnaires were selected and rest of the questionnaire was not including in the future analysis due to incomplete or invalid responses. After collecting the data the completed questionnaire were arranged and put numbering on them, these questionnaires were coded and entered into SPSS sheet for further regression analysis.

\subsection{Reliability Analysis:}

Over all Cronbach's alpha of Employee turnover questioner variable items are more than acceptable and recommended value 0.50 by Nominally (1970) and 0.60 by Moss et al . 
(1998). This shows that 19 item were reliable and valid to measure the opinions of employees.

Table 2: Reliability of measure instrument;

\begin{tabular}{|l|l|l|}
\hline Scale & Item & Cronbach Alpha \\
\hline Turnover intentions & 6 & 0.829 \\
Workplace Environment & 6 & 0.738 \\
Job Satisfaction & 4 & 0.839 \\
Job Performance & 3 & 0.679 \\
\hline
\end{tabular}

\section{Results and analysis}

\subsection{Profile of the Respondents:}

Demographic and Personal data such as, educational level, gender, age and income is given in the following table 2:

Table 3: Profile of the respondent;

\begin{tabular}{|l|l|l|l|}
\hline & Category & Frequency & Percentage \\
\hline Variable & & & \\
\hline Gender & Male & 90 & 60.0 \\
Female & 60 & 40.0 \\
\hline Age & $\begin{array}{l}\text { Below 18 } \\
18-25\end{array}$ & 1 & 0.6 \\
$25-35$ & 72 & 48.0 \\
$35-45$ & 39 & 26.0 \\
45 and above & 19 & 12.7 \\
Income & Below 15000 & 41 & 12.7 \\
$15001-30000$ & 41 & 34 & 27.3 \\
$30001-45000$ & 35001 and above & 34 & 22.7 \\
\hline
\end{tabular}




\begin{tabular}{|l|l|l|l|}
\hline Education & Metric & 4 & 2.7 \\
Intermediate & 6 & 4.0 \\
Graduation & 43 & 28.7 \\
Master & 74 & 49.3 \\
& M.phil/PhD & 23 & 15.3 \\
\hline
\end{tabular}

\subsection{Hypothesis testing result:}

\subsubsection{Workplace Environment, Employee turnover:}

According to the result of this study, the variable workplace environment has a significant positive relationship with $(\beta=0.233)$ and $(p<0.001)$. That means workplace environment contribute more than $23 \%$ on the employee turnover intention.

\subsubsection{Job Satisfaction, Employee turnover:}

The regression results of this study confirm the significant positive relationship between job satisfaction and employee turnover intention with $(\beta=0.320)$ and $(p<0.005)$ that means job satisfaction contributes more than $32 \%$ to job employee turnover intention.

\subsubsection{Job Performance, Employee turnover:}

The regression results of this study confirm the significant positive relationship between job performance and employee turnover intention with $(\beta=0.456)$ and $(p<0.004)$ that means job performance contributes more than $46 \%$ to job employee turnover intention.

Table 4: Regression Results;

\begin{tabular}{|l|l|l|l|l|l|l|}
\hline Hypothesis & Model Variable & Estimate & S.E. & C.R. & P & Results \\
\hline $\mathrm{H} 1 \mathrm{WPE}$ & $\begin{array}{l}\text { ET } \\
\text { ET }\end{array}$ & 0.233 & 0.063 & 1.986 & 0.001 & Supported \\
\hline $\mathrm{H} 2$ & $\begin{array}{l}\text { JS } \\
\text { ET }\end{array}$ & 0.456 & 0.071 & 2.214 & 0.004 & Supported \\
\hline $\mathrm{H} 2$ & JP & ET & 0.045 & 3.291 & 0.005 & Supported \\
\hline
\end{tabular}


Figure 2: Structure model results;

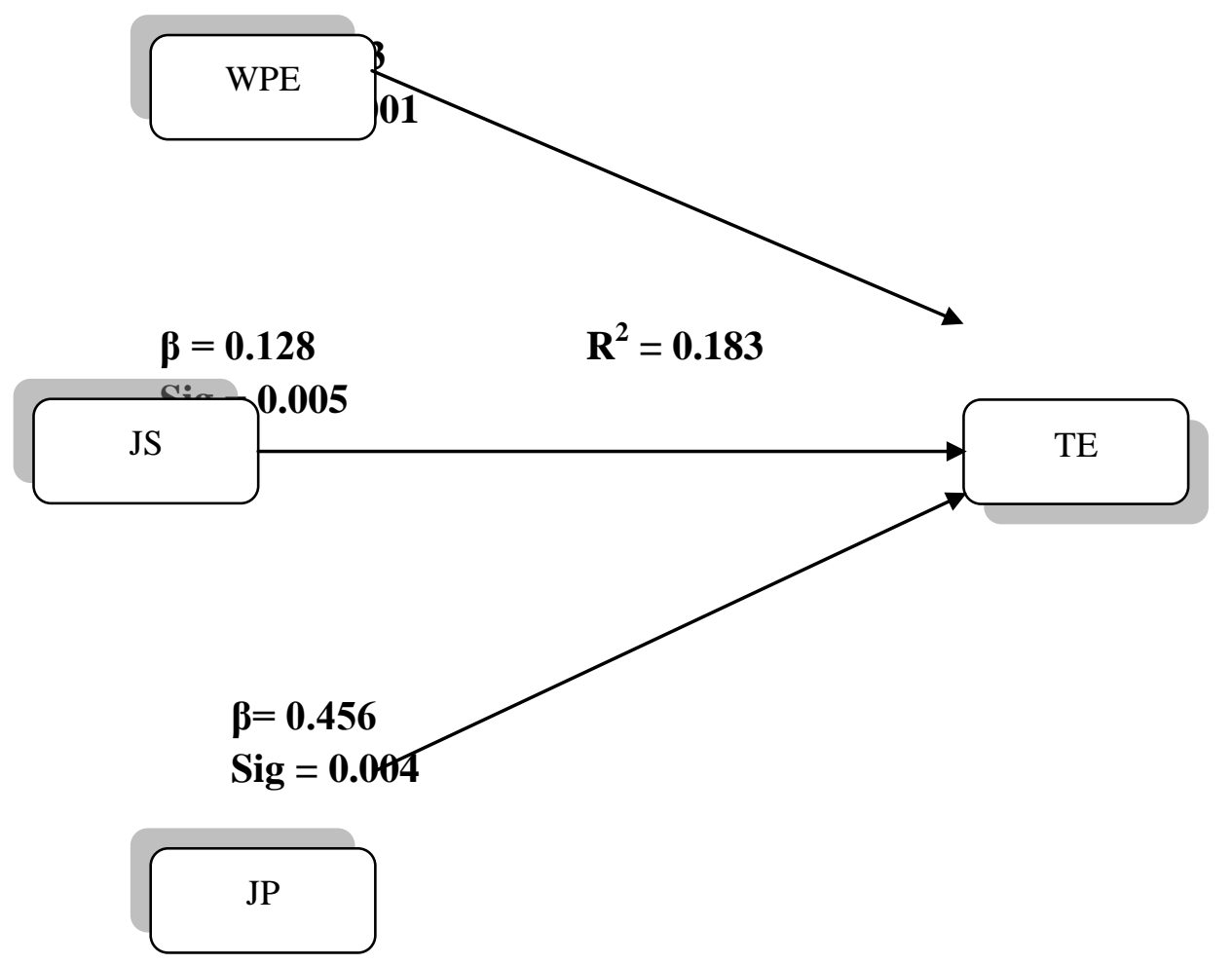

\section{Discussion}

The main purpose of the study is to establish the critical factors of the employee turnover and find the impact of employee turnover on employee loyalty in the service sector in Pakistan. Turnover construct contains three main factors; they are named as workplace environment, job satisfaction and job performance.

In this study, JP was found to be the most important factor on employee turnover with the value of its standardized regression weight being $0.456(\mathrm{p}, 0.004)$. This result shows that job performance provides various benefits to organizations such as diversification, increased productivity, decreased turnover, knowledge sharing and improved safety.

Workplace environment found another factor which significant influence on employee turnover intention of its regression weight being 0.233 ( $p, 0.001)$ To regulate the forecaster of physical workplace environment satisfaction, this study used linear fixation analytical thinking. Linear relation among autonomous variable and subordinate variable simulate linear fixation analysis. Secure relation between autonomous variable and subordinate variable are designate if the linear relationship is in straight form. To heighten the initiation and a beneficial organization culture, organization may formulate a learning environment through training and education. By educate and train the employees. We can reduce employee turnover in the company.

The third factor which influence on employee job satisfaction being weight 0.128 ( $\mathrm{p} 0.005$ ) 
on the conception of employee turnover the honor and acknowledgement was consider as the third significant component. This consequence affirms the study of Jun et al. (2006) and Maurer (2001). For the advance of employee participation and endure mutual work organizations must originate the stately reward and recognition systems. Department must honor as intend of accompaniment special functioning level on the recognition of employee's effort on excellence work. For the purpose of employee dedication to TQM execution, organization require qualified quality attempt to measure the performance. That found in entailment of public sector that both executive leaders and managers should be cognizant the significant of reward and recognition in service sector so they can reduce the turnover ratio in the organization.

\section{Limitations and future researches}

In this research, paper there is some restriction as matter. It is found that straight and convinced relation is sustain among employee turnover through study and the entire population of service sector in Pakistan's organization cannot be inferred due to this study access. The sore nature of the field and the possibilities of personal association even so the large-scale valued surveys are necessary for the selection of case study methodology. Another restriction on the complete employee turnover in the existing literature is the universal accede on the potential affect of vital component of employee satisfaction, employee performance and employee allegiance may not be exclusively specify through these three components. Rather many other components may act upon it, which is out the range of this research.

The link between JS and ETI have been given a thought, everybody knows that if we try to increase the satisfaction in a job, then we will reduce job turnover to some extent. In this paper, I have tried to mark certain areas, which are responsible for the ETI and effect the productivity of an organization. It is a known phenomenon that ETI can heavily charge the organization. The rate of production is lost within days (45 to 60 days) till vacancy created is filled, in addition time needed to train the new induction. If the rate of turnover is high, it exerts high pressure on company for the recruitment of new people.

\section{References:}

Moore, K.A. (2002), "Hospital restructuring: impact on nurses mediated by social support and a perception of challenge", Journal of Health and Human Services Administration.

WERC Sheet (2000), “Can incentive programs pay off?”, WERC Sheet, November, pp. 8-10.

Reda, S. (2001), "Employee incentives help retailers get maximum value from warehouse investments", Stores, pp. 1-3.

Major, B. and Konar, E. (1984), “An investigation of sex differences in pay expectations and their possible causes", Academy of Management Journal, Vol. 27, pp. 777-92.

Major, B., Testa, M. and Bylsma, W.H. (1991), "Responses to upward and downward social comparisons: the impact of esteem-relevance and perceived control”, in Suls, J. and Wills, 


\section{MInstitute Macrothink $_{\text {Int }}$}

International Journal of Human Resource Studies ISSN 2162-3058 2014, Vol. 4, No. 2

T.A. (Eds), Social Comparison: Contemporary Theory and Research, Erlbaum Associates, Hillsdale, NJ, pp. 237-60.

Oldham, G.R., Kulik, C.T., Ambrose, M.L., Stepina, L.P. and Brand, J.F. (1986), "Relations between job facet comparisons and employee reactions", Organizational Behavior and Human Decision Processes, Vol. 38, pp. 28-47.

Greenberg, J., Ashton-James, C.E. and Ashkanasy, N.M. (2007), "Social comparison processes in organizations", Organizational Behavior and Human Decision Processes, Vol. 102, pp. 22-41.

Buunk, B.P., Zurriaga, R., Gonzalez-Roma, V. and Subirats, M. (2003), "Engaging in upward and downward comparisons as a determinant of relative deprivation at work: a longitudinal study", Journal of Vocational Behavior, Vol. 62, pp. 370-88.

Buunk, A.P. and Gibbons, F.X. (2007), "Social comparison: the end of a theory and the emergence of a field", Organizational Behavior and Human Decision Processes, Vol. 107, pp. $3-21$.

Gill, H., Ahmed, I., Rizwan, M., Farid, S., Mustafa, M. Saher, S., Bashir, A. \& Tanveer, M. A. (2013) The Antecedents of Turnover Intention: A Comprehensive Model to Predict the Turnover intentions. Journal of Basic and Applied Scientific Research, 3(12), 392-402

Rizwan, M., Jaskani, J. H., Ameen, H., Hussain, S., Farooq, R. U., and Omair, M. (2013). Antecedents of Employee Satisfaction and it's impact on Job Turnover, International journal of Management Sciences and Business Research, 2(1), 55-64

Brown, D.J., Ferris, D.L., Heller, D. and Keeping, L.M. (2007), "Antecedents and consequences of the frequency of upward and downward social comparisons at work", Organizational Behavior and Human Decision Processes, Vol. 102, pp. 59-75.

Berger, S.M. (1977), "Social comparison, modeling, and perseverance", in Suls, J.M. and Miller, R.L. (Eds), Social Comparison Processes: Theoretical and Empirical Perspectives, Hemisphere, Washington, DC, pp. 209-34.

Hom, P.W., \&Griffeth, R.W. (1995).Employee turnover. Cincinnati: South Western College Publishing.

Hom, P.W., \&Kinichi, A.J. (2001). Towards a greater understanding of how dissatisfaction drives employee turnover. Academy of Management Journal, 44, 975-981.

Hwang, I., \&Kuo, J. (2006). Effects of job satisfaction and perceived alternative employment opportunities on turnover intention: An examination of public sector organizations. The Journal of American Academy of Business, 8, 254-259.

Firth, L., Mellor, D.J., Moore, K.A., \&Loquet, C. (2004). How can managers reduce employee intention to quit? Journal of Managerial Psychology, 19(2), 170-187.

Matthewsa, R.A., Booth, S.M., Taylor, C.F., \& Martin, T. (2011). A qualitative examination of the work-family interface: Parents of children with autism spectrum disorder. Journal of 
Vocational Behavior, doi:10.1016/j.jvb.2011.04.010.

Houlihan, M. (2001), "Managing to manage? Stories from the call center floor", Journal of European Industrial Training, Vol. 25 Nos 2/3/4, pp. 208-20.

Hutchinson, S., Purcell, J. and Kinnie, N. (2000), "The challenge of the call center", Human Resource Management International Digest, Vol. 8, pp. 4-8.

Taylor, P. and Bain, P. (1998), "An assembly line in the head: work and employee relations in the call center", Industrial Relations Journal, Vol. 30 No. 2, pp. 101-17.

Varca, P.E. (2001), "Service representatives, job control, and white-collar blues", Journal of Services Marketing, Vol. 15 No. 4, pp. 257-69.

Stephenson, F.J. and Fox, R.J. (1996), "Driver retention solutions: strategies for for-hire truckload (TL) employee drivers", Transportation Journal, Vol. 35 No. 4, pp. 12-25.

Keller, S.B. (2002), "Driver relationships with customers and driver turnover: key mediating variables affecting driver performance in the field", Journal of Business Logistics, Vol. 23, pp. 39-51.

Keller, S.B. and Ozment, J. (1999a), "Exploring dispatcher characteristics and their effect on driver retention", Transportation Journal, Vol. 39, pp. 20-34. Keller, S.B. and Ozment, J. (1999b), "Managing driver retention: effects of the dispatcher", Journal of Business Logistics, Vol. 20, pp. 97-119.

Min, H. and Emam, A. (2003), "Developing the profiles of truck drivers for their successful recruitment and retention: a data mining approach", International Journal of Physical Distribution \& Logistics Management, Vol. 33, pp. 149-62.

de Croon, E., Sluiter, J.K., Blonk, R., Broersen, J. and Frings-Dresen, M. (2004), "Stressful work, psychological job strain, and turnover: a 2-year prospective cohort study of truck drivers", Journal of Applied Psychology, Vol. 89, pp. 442-54.

Morrow, P.C., Suzuki, Y., Crum, M.R. and Ruben, R. (2005), "The role of leader-member exchange in high turnover work environments", Journal of Managerial Psychology, Vol. 20, pp. 681-94.

Spector, P.E. (1997), Job Satisfaction: Application, Assessment, Causes and Consequences: Advanced Topics in Organizational Behavior, Sage, London.

Greenberg, J. and Baron, R.A. (1997), Behavior in Organizations: Understanding and Managing the Human Side of Work, 6th ed., Prentice-Hall, Upper Saddle River, NJ. 